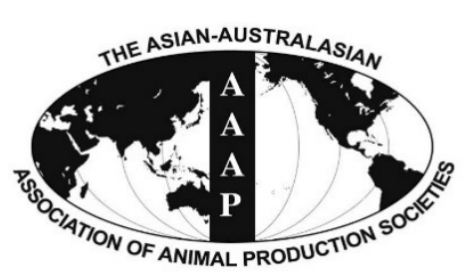

Open Access

Asian Australas. J. Anim. Sci.

Vol. 29, No. 11 : 1601-1607 November 2016

http://dx.doi.org/10.5713/ajas.16.0575

www.ajas.info

pISSN 1011-2367 elSSN 1976-5517

\title{
Use of Lysozyme as a Feed Additive on In vitro Rumen Fermentation and Methane Emission
}

\author{
Ashraf A. Biswas ${ }^{\text {a }}$, Sung Sill Lee ${ }^{1, a}$, Lovelia L. Mamuad, Seon-Ho Kim, Yeon-Jae Choi, \\ Gui-Seck Bae ${ }^{2}$, Kichoon Lee ${ }^{3}$, Ha-Guyn Sung ${ }^{4}$, and Sang-Suk Lee* \\ Ruminant Nutrition and Anaerobe Laboratory, Department of Animal Science and Technology, \\ Sunchon National University, Suncheon 540-742, Korea
}

\begin{abstract}
This study was conducted to determine the effect of lysozyme addition on in vitro rumen fermentation and to identify the lysozyme inclusion rate for abating methane $\left(\mathrm{CH}_{4}\right)$ production. An in vitro ruminal fermentation technique was done using a commercial concentrate to rice straw ratio of 8:2 as substrate. The following treatments were applied wherein lysozyme was added into 1 mg dry matter substrate at different levels of inclusion: Without lysozyme, 2,000, 4,000, and 8,000 U lysozyme. Results revealed that, lysozyme addition had a significant effect on $\mathrm{pH}$ after $24 \mathrm{~h}$ of incubation, with the highest $\mathrm{pH}(\mathrm{p}<0.01)$ observed in $8,000 \mathrm{U}$ lysozyme, followed by the 4,000 U, 2,000 U, and without lysozyme. The highest amounts of acetic acid, propionic acid ( $<<0.01)$ and total volatile fatty acid (TVFA) $(\mathrm{p}<0.05)$ were found in $8,000 \mathrm{U}$ after $24 \mathrm{~h}$ of incubation. The $\mathrm{CH}_{4}$ concentration was the lowest in the 8,000 $\mathrm{U}$ and the highest in the without lysozyme addition after $24 \mathrm{~h}$ of incubation. There was no significant differences in general bacteria, methanogen, or protozoan DNA copy number. So far, addition of lysozyme increased the acetate, propionate, TVFA, and decreased $\mathrm{CH}_{4}$ concentration. These results suggest that lysozyme supplementation may improve in vitro rumen fermentation and reduce $\mathrm{CH}_{4}$ emission. (Key Words: In vitro, Lysozyme, Methane, Ruminant, Volatile Fatty Acid)
\end{abstract}

\section{INTRODUCTION}

Lysozyme is a universal enzyme found in living organisms having diverse role starting from digestion to immune response. Lysozymes (e.g. 1, 4- $\beta$-N-acetylmuramidase) have both enzymatic and bacteriolytic activity. They cleave the glycosidic linkage in the peptidoglycan component of gram-positive bacterial cell walls, which ultimately leads to

\footnotetext{
* Corresponding Author: Sang-Suk Lee. Tel: +82-61-750-3237, Fax: +82-61-750-3237, E-mail: rumen@sunchon.ac.kr

${ }^{1}$ Division of Applied Life Science (BK21+, IALS), Gyeongsang National University, Jinju 52828, Korea.

2 Department of Animal Science and Technology, Chung-Ang University, Anseong 456-756, Korea.

3 Department of Animal Sciences, The Ohio State University, Columbus, OH 43210, USA.

${ }^{4}$ Department of Animal Science \& Technology, Sangji University, Wonju 26339, Korea.

a These authors contributed equally to the work.

Submitted Jul. 28, 2016; Revised Sept. 12, 2016; Accepted Sept. 28, 2016
}

cell death (Ellison and Giehl, 1991). Interestingly, lysozymes lyse the microbial cells from the outside, in addition to inducing microbial autolysis (Ibrahim et al., 2001). Grampositive bacteria are susceptible to the action of lysozyme but most of the gram-negative bacteria are not for their thick outer membrane beyond the peptidoglycan layer. In the animal production sector, antimicrobials, such as antibiotics, are used at low doses as growth promoters for their bactericidal effect. But, the adverse effects of the indiscriminate use of antibiotics (such as antibiotic resistance) on the animal as well as environment make the animal industry in vulnerable condition. So, animal production people as well as animal scientists are inspired to identify the alternative of antibiotic for sustainable animal production system. For the enzymatic and bacteriolytic characteristics of lysozyme, scientists are encouraging the application of lysozymes for enhancing growth performance and as an antimicrobials (Nyachoti et al., 2012). Lysozymes have been shown to reduce diarrhoea incidence during the preweaning 
period of calves and tend to increase average daily gain (ADG) (Goncu et al., 2012). In addition, they have been shown to have an ADG-increasing capability in pigs (May et al., 2012). However, there is no information available about the effects of lysozymes on in vitro rumen fermentation and methane $\left(\mathrm{CH}_{4}\right)$ emission in ruminants. Therefore, this study aimed to evaluate the effects of lysozymes on in vitro fermentation parameters and to identify the inclusion rate of lysozymes for abating in vitro $\mathrm{CH}_{4}$ production.

\section{MATERIALS AND METHODS}

An in vitro ruminal fermentation technique was adopted using late fattening commercial pelleted concentrate (Nonghyup co., Haman, Korea) and rice straw (8:2) as substrate. In this experiment, we used liquid lysozyme collected from Celltech co., Ltd., Eumseong, Korea containing 150,000 units $/ \mathrm{mL}$. In addition to the control (no added lysozyme), the following treatments were applied: $2,000,4,000$, and $8,000 \mathrm{U}$ lysozyme (hereafter referred to as $\mathrm{T} 1, \mathrm{~T} 2$, and $\mathrm{T} 3$, respectively), which were added to $1 \mathrm{~g}$ dry matter (DM) substrate. Inclusion level of lysozyme as U/g DM substrate were based on the previous research work done by Nyachoti et al. (2012). On the basis of inclusion level (U) and lysozyme content $(\mathrm{U} / \mathrm{mL})$ of liquid lysozyme, we have used $13.33 \mu \mathrm{L}, 26.66 \mu \mathrm{L}$, and $53.33 \mu \mathrm{L}$ liquid lysozyme in 1 g DM substrate for $\mathrm{T} 1, \mathrm{~T} 2$, and $\mathrm{T} 3$ treatments, respectively.

\section{In vitro experiment}

Ruminal contents were obtained from a 48-month old rumen-cannulated Holstein cow $(650 \mathrm{~kg})$ fed rice straw and commercial pelleted concentrate ( $8: 2$ ratio) twice a day. The supplied rice straw contained $4.45 \%$ crude protein (CP) and $38.29 \%$ total digestible nutrients (TDN), whereas the concentrate contained $12 \% \mathrm{CP}$ and $72 \% \mathrm{TDN}$. The pooled ruminal contents were squeezed and the extracted fluids were collected in a glass bottle after straining through cheese cloth that had been folded four times. The bottle was subsequently capped and immediately transported to the laboratory while maintaining the temperature at $39^{\circ} \mathrm{C}$. In the laboratory, the bottle was placed in a water bath at $39^{\circ} \mathrm{C}$. The bottle was shaken vigorously by hand, prior to mixing with a buffer. The particle-free rumen fluid was transferred to a buffer medium (pH 6.9) at a 1:3 rumen fluid: buffer ratio. The buffer medium was prepared according to the method described by Asanuma et al. (1999). Under a constant flow of $\mathrm{N}_{2}$ gas, $100 \mathrm{~mL}$ of buffered rumen fluid was anaerobically transferred to 160 $\mathrm{mL} 96$ serum bottles containing $1 \mathrm{~g}$ substrate $(1 \mathrm{~mm}$ particle size) together with the different concentrations of lysozyme. The serum bottles were subsequently sealed with rubber septum stoppers and aluminium caps followed by incubation at $39^{\circ} \mathrm{C}$ for $0,6,12$, and $24 \mathrm{~h}$ in a $120 \mathrm{rpm}$ shaking incubator as described by Hattori and Matsui (2008). For each incubation time, three replicates per experimental treatment were used.

$\mathrm{pH}$, total gas (TG), $\mathrm{CH}_{4}$, ammonia nitrogen $\left(\mathrm{NH}_{3}-\mathrm{N}\right)$, acetic acid, propionic acid, butyric acid and total volatile fatty acid (VFA) were analysed at each incubation time. Fifteen $\mathrm{ml}$ samples were collected from each of the serum bottles into the falcon tube and kept at $-80^{\circ} \mathrm{C}$ until further analysis of VFA, $\mathrm{NH}_{3}-\mathrm{N}$, and molecular study. The gas produced inside the bottle was estimated for TG and gas sample trapped inside vacuum tubes and stored in a refrigerator until $\mathrm{CH}_{4}$ determination. In vitro $\mathrm{DM}$ and organic matter (OM) disappearance were estimated after $0,6,12$, and $24 \mathrm{~h}$ of incubation.

\section{Analyses of in vitro fermentation parameters}

Fermentation parameters were checked at the end of each incubation time. $\mathrm{pH}$ was determined using a Pinnacle series M530p meter (Schott Instruments, Mainz, Germany). Before opening serum bottle, an EA-6 (Sun Bee instrument, Inc., Seoul, Korea) pressure sensor meter was used to measure TG production from each of the serum bottles. Duplicates of 1 $\mathrm{mL}$ fermentation samples from each of the serum bottles were immediately centrifuged at $13,000 \mathrm{rpm}$ for $10 \mathrm{~min}$ at $4^{\circ} \mathrm{C}$ using a Micro 17TR centrifuge (Hanil Science Industrial Co. Ltd., Gimpo, Korea). The supernatant was transferred to two $1.5 \mathrm{~mL}$ Eppendorf tubes and deep-frozen at $-80^{\circ} \mathrm{C}$ until $\mathrm{NH}_{3}-\mathrm{N}$ and VFA analysis also remaining pellet were preserved in the same temperature for DNA copy number estimation. At the time of $\mathrm{NH}_{3}-\mathrm{N}$ and VFA analysis, the samples contained in the Eppendorf tubes were thawed at room temperature and used for measuring $\mathrm{NH}_{3}-\mathrm{N}$, individual VFA i.e. acetic acid, propionic acid, butyric acid and total VFA. The measurements of $\mathrm{NH}_{3}-\mathrm{N}$ were performed according to the methods developed by Chaney and Marbach (1962), at an optical density of $630 \mathrm{~nm}$ using a Libra S22 spectrophotometer (Biochrom Ltd., CB40FJ, Cambourne, England). The VFA measurements followed the methods described by Han et al. (2005) and Tabaru et al. (1988). We used high performance liquid chromatography (Agilent Technologies 1200 series, Waldbronn, Baden-Wurttemberg, Germany) using a UV detector set at 210 and $220 \mathrm{~nm}$ and a METACARB87H (Varian, Palo Alto, CA, USA) column with $0.0085 \mathrm{~N} \mathrm{H}_{2} \mathrm{SO}_{4}$ solvent as buffer at a flow rate of 0.6 $\mathrm{mL} / \mathrm{min}$. The individual VFA concentration in $\mathrm{mM}$ was calculated as parts per million divided by the molecular weight. Total VFA were calculated with sum of individual VFA and acetate/propionate ratio (A/P) value was calculated as acetic acid divided by propionic acid.

\section{Determination of in vitro dry matter and organic matter disappearance}

At the start of the in vitro rumen fermentation, the 
Table 1. Primer used in quantitative polymerase chain reaction

\begin{tabular}{llccc}
\hline Target microbes & \multicolumn{1}{c}{ Primer sequences } & $\begin{array}{c}\text { Annealing } \\
\text { temp. }\left({ }^{\circ} \mathrm{C}\right)\end{array}$ & $\begin{array}{c}\text { Product } \\
\text { size }\end{array}$ & Reference \\
\hline General bacteria & 1114F: 5'-CGG CAA CGA GCG CAA CCC-3' & 60 & 130 & Denman and McSweeney, 2006 \\
Methanogens & $\begin{array}{l}\text { 1275R: } \text { 3'-CCA TTG TAG CAC GTG TGT AGC C-5' }^{\prime} \text { qmcraA-F: 5'-GGA TTA GAT ACC CSG GTA GT-3' } \\
\text { qmerA-R: 3'-GTT GAR TCC AAT TAA ACC GCA-5' }\end{array}$ & 60 & 140 & Denman and McSweeney, 2006 \\
Protozoa & $\begin{array}{l}\text { F: 5'-GCT TTC GWT GGT AGT GTA TT-3' } \\
\text { R: 3'-CTT GCC CTC YAA TCG TWC T-5' }\end{array}$ & 60 & 223 & Denman and McSweeney, 2006 \\
\hline
\end{tabular}

substrate $\mathrm{DM}$ and $\mathrm{OM}$ were determined by drying at $105^{\circ} \mathrm{C}$ for $16 \mathrm{~h}$ and ashing at $550^{\circ} \mathrm{C}$ for $12 \mathrm{~h}$, respectively. The resulting percent $\mathrm{DM}$ and $\mathrm{OM}$ were used to compute the initial DM $\left(\mathrm{DM}_{\mathrm{i}}\right)$ and $\mathrm{OM}\left(\mathrm{OM}_{\mathrm{i}}\right)$ content $(\mathrm{g})$ of the substrate. After each of the specified incubation periods, every treatment bearing three replicates fermentation samples from each serum bottle were drained in dried, pre-weighed nylon bags and knotted using nylon thread. They were then rinsed in flowing water until the turbidity of the rinse water disappeared. The final DM $\left(\mathrm{DM}_{\mathrm{f}}\right)$ and $\mathrm{OM}\left(\mathrm{OM}_{\mathrm{f}}\right)$ of the substrate were determined using the same conditions as applied when determining $\mathrm{DM}_{\mathrm{i}}$ and $\mathrm{OM}_{\mathrm{i}}$. The $\mathrm{DM}$ and $\mathrm{OM}$ disappearance $(\%)$ were calculated as $\left(\left[\mathrm{DM}_{\mathrm{i}}-\mathrm{DM}_{\mathrm{f}}\right] / \mathrm{DM}_{\mathrm{i}}\right) \times$ 100 and $\left(\left[\mathrm{OM}_{\mathrm{i}}-\mathrm{OM}_{\mathrm{f}}\right] / \mathrm{OM}_{\mathrm{i}}\right) \times 100$, respectively.

\section{Methane estimation}

The samples contained in the vacuum tube were analysed for $\mathrm{CH}_{4}$, using gas chromatography (Agilent Technologies HP 5890, Germany) using a TCD detector with a Carboxen 1006PLOT capillary column $30 \mathrm{~m} \times 0.53 \mathrm{~mm}$ (Supelco, Bellefonte, PA, USA).

\section{Quantitative real-time polymerase chain reaction}

General bacteria, methanogens, and protozoan DNA copies were estimated using the protocol of Denman and McSweeney (2006). The DNA concentration from the extracted gDNA from each pelleted sample was determined using an Epoch Microplate Spectrophotometer (Biotek, Winooski, VT, USA). Target-specific forward and reverse polymerase chain reaction (PCR) primers were used (Table 1). Amplification was done using Eco Real-Time PCR (Illumina, Inc., San Diego, CA, USA) in a total reaction volume of $20 \mu \mathrm{L}$ per reaction mixture containing $10 \mu \mathrm{L}$ of $2 \mathrm{X}$ qPCRBIO SyGreen Mix, $0.8 \mu \mathrm{L}$ each forward and reverse PCR primers, and $8.4 \mu \mathrm{L}$ template DNA of $50 \mathrm{ng} / \mu \mathrm{L}$ in sterile distilled water.

\section{Statistical analysis}

Data were analysed by analysis of variance using a general linear model for a complete randomised design. All treatments were conducted in triplicate. Duncan's multiple range test and orthogonal polynomial contrast were used to identify differences between and among treatments and control. A $\mathrm{p} \leq 0.05$ was considered to indicate statistical significance. All analyses were carried out using Statistical Analysis System (SAS) (SAS, 2004) (version 9.1; SAS Inst. Inc., Cary, NC, USA).

\section{RESULTS}

There was no significant difference in $\mathrm{pH}$ after 6 and 12 $\mathrm{h}$ of incubation. After $24 \mathrm{~h}$ of incubation, the $\mathrm{pH}$ in the control group was the lowest $(\mathrm{p}<0.01)$, subsequently increase in $\mathrm{T} 1$ then $\mathrm{T} 2$ and the highest $\mathrm{pH}$ was in the $\mathrm{T} 3$ treatment group (Table 2). In the case of TG, no significant differences were observed after 12 and $24 \mathrm{~h}$. However, a tendency towards higher TG in treatment groups compared to the control was observed after 12 and $24 \mathrm{~h}$ (Table 2). We found no differences in $\mathrm{NH}_{3}-\mathrm{N}$ after 12 or $24 \mathrm{~h}$ of incubation. Nevertheless, at $6 \mathrm{~h}$ of incubation, the $\mathrm{NH}_{3}-\mathrm{N}$ differed significantly among the treatments $(p=0.05)$ with the highest value observed in the T3 treatment (Table 2).

There were significant differences in acetic acid at all incubation periods except after $6 \mathrm{~h}$ of incubation (Table 3 ). The highest $(\mathrm{p}<0.01)$ acetic acid was observed in T3 (41.61 $\mathrm{mM}$ ) after $24 \mathrm{~h}$ of incubation followed by $\mathrm{T} 2, \mathrm{~T} 1$, and the control. Likewise, we found a significant difference $(\mathrm{p}<0.01)$ in propionic acid after 12 and $24 \mathrm{~h}$ of incubation with 12.21 $\mathrm{mM}$ and $12.01 \mathrm{mM}$, respectively. The highest and lowest propionic acid concentrations were found in T3 and control, respectively, after 12 and $24 \mathrm{~h}$ of incubation. In the case of butyric acid, there was no significant difference after $24 \mathrm{~h}$ but there was a tendency towards T3 having the highest butyric acid. Significant differences in total VFA $(p<0.05)$ were found in all treatments except at $6 \mathrm{~h}$ of incubation. The highest total VFA was observed in T3 after 12 and $24 \mathrm{~h}$ of incubation (Table 3). There were no significant differences in $\mathrm{A} / \mathrm{P}$ value after 6,12 , or $24 \mathrm{~h}$ of incubation, although there was a tendency towards the highest $\mathrm{A} / \mathrm{P}$ value in the control after 12 , and $24 \mathrm{~h}$ of incubation (Table 3 ).

There were no significant differences in DM or OM disappearance, but there was a tendency towards higher DM disappearance in T3 compared to the control after $24 \mathrm{~h}$ of incubation (Table 4). Likewise, after $24 \mathrm{~h}$ of incubation the tended to highest OM disappearance was found in T3 (Table 4). In the case of $\mathrm{CH}_{4}$ concentration, significant differences 
Table 2. $\mathrm{pH}$, total gas and ammonia nitrogen $\left(\mathrm{NH}_{3}-\mathrm{N}\right)$ production from in vitro rumen fermentation by the addition of lysozyme

\begin{tabular}{|c|c|c|c|c|c|c|c|}
\hline \multirow{2}{*}{ Parameters/time } & \multicolumn{4}{|c|}{ Treatments $^{1}$} & \multirow{2}{*}{ SEM } & \multicolumn{2}{|c|}{$\mathrm{p}$ value $^{2}$} \\
\hline & Control & $\mathrm{T} 1$ & $\mathrm{~T} 2$ & $\mathrm{~T} 3$ & & All & $\mathrm{C}$ vs T \\
\hline \multicolumn{8}{|l|}{ pH value } \\
\hline $0 \mathrm{~h}$ & $6.16^{\mathrm{d}}$ & $6.20^{c}$ & $6.23^{\mathrm{b}}$ & $6.26^{\mathrm{a}}$ & 0.008 & $<0.001$ & $<0.001$ \\
\hline $6 \mathrm{~h}$ & 5.56 & 5.53 & 5.61 & 5.59 & 0.019 & 0.097 & 0.354 \\
\hline $12 \mathrm{~h}$ & 5.34 & 5.37 & 5.37 & 5.37 & 0.008 & 0.152 & 0.032 \\
\hline $24 \mathrm{~h}$ & $5.20^{\mathrm{c}}$ & $5.21^{\mathrm{bc}}$ & $5.23^{\mathrm{b}}$ & $5.25^{\mathrm{a}}$ & 0.005 & 0.002 & 0.002 \\
\hline \multicolumn{8}{|l|}{ Total gas (mL) } \\
\hline $0 \mathrm{~h}$ & $3.75^{\mathrm{a}}$ & $3.17^{b}$ & $3.67^{\mathrm{a}}$ & $3.75^{\mathrm{a}}$ & 0.124 & 0.010 & 0.144 \\
\hline $6 \mathrm{~h}$ & $51.33^{\mathrm{b}}$ & $54.20^{\mathrm{ab}}$ & $53.20^{\mathrm{b}}$ & $57.00^{\mathrm{a}}$ & 1.097 & 0.020 & 0.019 \\
\hline $12 \mathrm{~h}$ & 87.25 & 88.75 & 87.75 & 88.50 & 1.475 & 0.911 & 0.578 \\
\hline $24 \mathrm{~h}$ & 96.17 & 99.00 & 98.83 & 98.83 & 1.307 & 0.431 & 0.106 \\
\hline \multicolumn{8}{|l|}{$\mathrm{NH}_{3}-\mathrm{N}(\mathrm{mM})$} \\
\hline $0 \mathrm{~h}$ & 31.28 & 32.09 & 34.28 & 34.72 & 1.405 & 0.697 & 0.440 \\
\hline $6 \mathrm{~h}$ & $34.65^{\mathrm{b}}$ & $38.46^{\mathrm{ab}}$ & $37.13^{\mathrm{b}}$ & $44.57^{\mathrm{a}}$ & 2.081 & 0.050 & 0.072 \\
\hline $12 \mathrm{~h}$ & 36.67 & 38.73 & 42.93 & 45.82 & 2.159 & 0.203 & 0.157 \\
\hline $24 \mathrm{~h}$ & 41.58 & 44.59 & 43.40 & 45.99 & 2.424 & 0.697 & 0.357 \\
\hline
\end{tabular}

SEM, standard error of the mean.

${ }^{1}$ Control: without lysozyme, T1: 2,000 unit lysozyme, T2: 4,000 unit lysozyme, T3: 8,000 unit lysozyme.

${ }^{2} \mathrm{C}$ vs $\mathrm{T}$ is the comparison between control and treatment.

${ }^{a, b, c}$ Means in the same row with different superscript are significantly different $(\mathrm{p}<0.05)$.

Table 3. Volatile fatty acid (VFA) production $(\mathrm{mM})$ and A/P ratio from in vitro fermentation by the addition of lysozyme

\begin{tabular}{|c|c|c|c|c|c|c|c|}
\hline \multirow{2}{*}{ Parameters/time } & \multicolumn{4}{|c|}{ Treatments $^{1}$} & \multirow{2}{*}{ SEM } & \multicolumn{2}{|c|}{$\mathrm{p}$ value $^{2}$} \\
\hline & Control & $\mathrm{T} 1$ & $\mathrm{~T} 2$ & $\mathrm{~T} 3$ & & All & C vs T \\
\hline \multicolumn{8}{|l|}{ Acetic acid } \\
\hline $0 \mathrm{~h}$ & $26.30^{\mathrm{b}}$ & $26.76^{\mathrm{a}}$ & $26.72^{\mathrm{a}}$ & $26.87^{\mathrm{a}}$ & 0.068 & 0.002 & 0.001 \\
\hline $6 \mathrm{~h}$ & 37.20 & 37.04 & 36.98 & 38.18 & 0.274 & 0.109 & 0.622 \\
\hline $12 \mathrm{~h}$ & $37.77^{\mathrm{d}}$ & $38.63^{c}$ & $39.35^{\mathrm{b}}$ & $40.40^{\mathrm{a}}$ & 0.168 & $<0.001$ & $<0.001$ \\
\hline $24 \mathrm{~h}$ & $39.17^{c}$ & $39.92^{\mathrm{bc}}$ & $40.48^{\mathrm{b}}$ & $41.61^{\mathrm{a}}$ & 0.237 & 0.003 & 0.004 \\
\hline \multicolumn{8}{|l|}{ Propionic acid } \\
\hline $0 \mathrm{~h}$ & 7.82 & 7.78 & 7.77 & 7.76 & 0.023 & 0.460 & 0.145 \\
\hline $6 \mathrm{~h}$ & 10.61 & 10.62 & 10.21 & 11.36 & 0.181 & 0.078 & 0.711 \\
\hline $12 \mathrm{~h}$ & $11.04^{\mathrm{b}}$ & $11.39^{\mathrm{b}}$ & $11.98^{\mathrm{a}}$ & $12.21^{\mathrm{a}}$ & 0.134 & 0.002 & 0.001 \\
\hline $24 \mathrm{~h}$ & $10.67^{\mathrm{b}}$ & $11.57^{\mathrm{a}}$ & $11.50^{\mathrm{a}}$ & $12.01^{\mathrm{a}}$ & 0.175 & 0.008 & 0.002 \\
\hline \multicolumn{8}{|l|}{ Butyric acid } \\
\hline $0 \mathrm{~h}$ & 4.65 & 4.60 & 4.58 & 4.47 & 0.027 & 0.012 & 0.015 \\
\hline $6 \mathrm{~h}$ & 9.06 & 9.46 & 8.76 & 9.28 & 0.207 & 0.191 & 0.676 \\
\hline $12 \mathrm{~h}$ & $15.42^{\mathrm{a}}$ & $15.23^{\mathrm{a}}$ & $13.71^{\mathrm{b}}$ & $13.52^{\mathrm{b}}$ & 0.188 & $<0.001$ & 0.001 \\
\hline $24 \mathrm{~h}$ & 16.14 & 15.91 & 15.99 & 16.19 & 0.306 & 0.934 & 0.798 \\
\hline \multicolumn{8}{|l|}{ Total VFA } \\
\hline $0 \mathrm{~h}$ & $38.77^{\mathrm{b}}$ & $39.13^{\mathrm{a}}$ & $39.06^{\mathrm{a}}$ & $39.09^{\mathrm{a}}$ & 0.071 & 0.046 & 0.008 \\
\hline $6 \mathrm{~h}$ & 56.87 & 57.11 & 56.94 & 58.82 & 0.701 & 0.185 & 0.340 \\
\hline $12 \mathrm{~h}$ & $64.22^{c}$ & $65.25^{\mathrm{ab}}$ & $65.04^{\mathrm{bc}}$ & $66.13^{\mathrm{a}}$ & 0.273 & 0.010 & 0.005 \\
\hline $24 \mathrm{~h}$ & $66.29^{\mathrm{b}}$ & $67.40^{\mathrm{b}}$ & $67.98^{\mathrm{ab}}$ & $69.81^{\mathrm{a}}$ & 0.512 & 0.039 & 0.040 \\
\hline \multicolumn{8}{|l|}{$\mathrm{A} / \mathrm{P}$ ratio } \\
\hline $0 \mathrm{~h}$ & $3.36^{\mathrm{b}}$ & $3.44^{\mathrm{a}}$ & $3.44^{\mathrm{a}}$ & $3.48^{\mathrm{a}}$ & 0.012 & 0.003 & 0.001 \\
\hline $6 \mathrm{~h}$ & 3.51 & 3.49 & 3.63 & 3.36 & 0.037 & 0.073 & 0.864 \\
\hline $12 \mathrm{~h}$ & 3.42 & 3.39 & 3.29 & 3.31 & 0.042 & 0.239 & 0.143 \\
\hline $24 \mathrm{~h}$ & 3.57 & 3.45 & 3.52 & 3.47 & 0.041 & 0.329 & 0.149 \\
\hline
\end{tabular}

$\mathrm{A} / \mathrm{P}$, acetate/propionate; SEM, standard error of the mean.

${ }^{1}$ Control: without lysozyme, T1: 2,000 unit lysozyme, T2: 4,000 unit lysozyme, T3: 8,000 unit lysozyme.

${ }^{2} \mathrm{C}$ vs $\mathrm{T}$ is the comparison between control and treatment.

${ }^{a, b, c}$ Means in the same row with different superscript are significantly different $(p<0.05)$. 
Table 4. Dry matter and organic matter disappearance (\%) from as influenced by the addition of lysozyme

\begin{tabular}{|c|c|c|c|c|c|c|c|}
\hline \multirow{2}{*}{$\begin{array}{l}\text { Parameters } \\
\text { /time }\end{array}$} & \multicolumn{4}{|c|}{ Treatments $^{1}$} & \multirow{2}{*}{ SEM } & \multicolumn{2}{|c|}{$\mathrm{p}$ value $^{2}$} \\
\hline & Control & $\mathrm{T} 1$ & $\mathrm{~T} 2$ & T3 & & All & $\mathrm{C}$ vs \\
\hline \multicolumn{8}{|c|}{ DM disappearance } \\
\hline $0 \mathrm{~h}$ & 29.18 & 30.95 & 31.85 & 32.52 & 1.631 & 0.682 & 0.30 \\
\hline $6 \mathrm{~h}$ & 47.10 & 47.68 & 47.08 & 48.37 & 1.084 & 0.854 & 0.70 \\
\hline $12 \mathrm{~h}$ & 57.25 & 57.66 & 55.80 & 56.33 & 0.713 & 0.341 & 0.43 \\
\hline $24 \mathrm{~h}$ & 57.10 & 60.12 & 59.13 & 59.40 & 1.738 & 0.722 & 0.32 \\
\hline \multicolumn{8}{|c|}{ OM disappearance } \\
\hline $0 \mathrm{~h}$ & 25.58 & 26.95 & 27.69 & 28.38 & 1.351 & 0.696 & 0.32 \\
\hline $6 \mathrm{~h}$ & 42.39 & 42.39 & 42.68 & 43.86 & 1.011 & 0.708 & 0.673 \\
\hline $12 \mathrm{~h}$ & 51.79 & 52.23 & 50.65 & 50.92 & 0.624 & 0.318 & 0.472 \\
\hline $24 \mathrm{~h}$ & 52.61 & 53.61 & 54.26 & 54.37 & 1.602 & 0.843 & 0.45 \\
\hline
\end{tabular}

SEM, standard error of the mean; DM, dry matter; OM, organic matter.

${ }^{1}$ Control: without lysozyme, T1: 2,000 unit lysozyme, T2: 4,000 unit lysozyme, T3: 8,000 unit lysozyme.

${ }^{2} \mathrm{C}$ vs $\mathrm{T}$ is the comparison between control and treatment.

Means in the same row with different superscript are significantly different $(\mathrm{p}<0.05)$.

were observed at all incubation times, except after $6 \mathrm{~h}$ of incubation. After $24 \mathrm{~h}$, the lowest $\mathrm{CH}_{4}$ concentration was observed in the $\mathrm{T} 3$ treatment, followed by $\mathrm{T} 2$ and $\mathrm{T} 1$ and highest $\mathrm{CH}_{4}$ concentration was found in the control (Figure 1). Although non-significant, the general bacterial DNA copy number tended to be lower in the treatment groups (T1 to T3), compared to the control. Likewise, there were no significant differences in the case of methanogen DNA copy number. The protozoan DNA copy numbers were not significantly different either, but the lowest DNA copy numbers were found in the T3 treatment (Table 5).

\section{DISCUSSION}

Lysozyme is an antimicrobial enzyme that can lyses bacterial cell walls by hydrolysing the polysaccharide component (Salton, 1957). It cleaves the gram-positive bacterial glycosidic linkage in the peptidoglycan component (Ellision and Giehl, 1991) but most of gram negative bacteria are not susceptible to lysozyme for their protective outer membrane. Also, lysozyme has enzymatic activity on digestion process. According to Sahoo et al. (2012), lysozyme has been recruited as a digestive enzyme for some of animals. They have also mentioned that lysozyme has

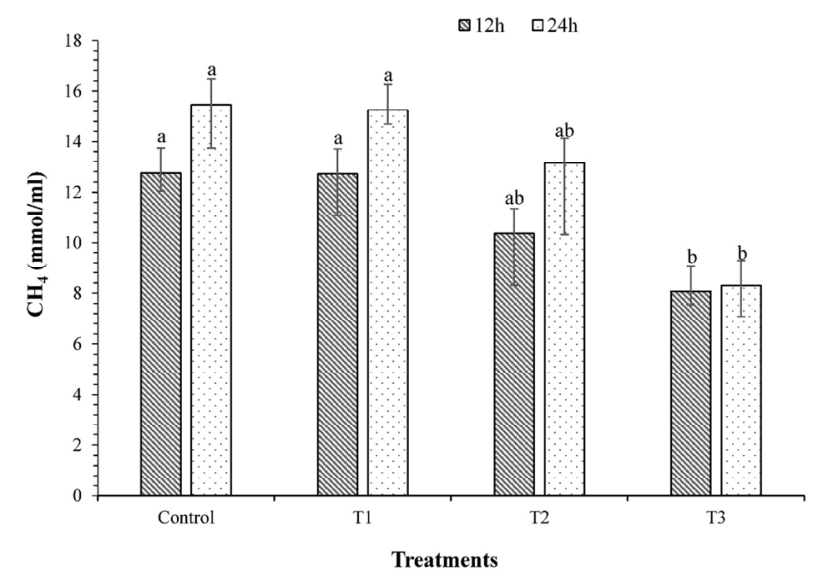

Figure 1. Methane concentration $(\mathrm{mmol} / \mathrm{mL})$ from as influenced by the addition of lysozyme. Control: without lysozyme, T1: 2,000 unit lysozyme, T2: 4,000 unit lysozyme, T3: 8,000 unit lysozyme. a,b Treatments with different letters are different at $\mathrm{p}<0.05$.

diverse role including digestion. In the current study, we found that the $\mathrm{pH}$ after $24 \mathrm{~h}$ of incubation was the lowest in the control group with sequentially increasing from low to high inclusion level of lysozyme, which is suggested that the high $\mathrm{pH}$ found in the treatment groups containing higher amounts of lysozyme, was due to the high $\mathrm{pH}$ (8.99) of the lysozyme used in this experiment. This high $\mathrm{pH}$ can reduce the ruminal acidosis (Owens et al., 1998) which will be helpful for ruminant production especially high yielding animal.

Significantly higher contents of acetic acid, propionic acid, and total VFA of this study after $24 \mathrm{~h}$ of incubation supported by Giraldo et al. (2007) who observed increased total VFA using fibrolytic enzyme (cellulase and xylanase) addition in in vitro trials. This increased VFA could be the effect of enzymatic degradation of feed material through hydrolytic action. Current experimental increased total VFA, which ultimately reflects better performance, also agrees with the findings of May et al. (2012) and Goncu et al. (2012), who reported tended to increase in daily gain of calves fed $10 \mathrm{mg}$ lysozyme/L of milk. In addition, Nyachoti et al. (2012) also reported a tendency to an ADG increase in piglets, when $0.1 \%$ and $0.2 \%$ of lysozyme were added to the basal diet.

Digestibility of different feed ingredients is an important factor for the $\mathrm{CH}_{4}$ production (Kim et al., 2013). We found no effect of lysozyme on DM or OM disappearance,

Table 5. Microbial DNA copies from as influenced by the addition of lysozyme after $24 \mathrm{~h}$ of incubation

\begin{tabular}{|c|c|c|c|c|c|c|c|}
\hline \multirow{2}{*}{ Target microbes } & \multicolumn{4}{|c|}{ Treatment $^{1}$} & \multirow{2}{*}{ SEM } & \multicolumn{2}{|c|}{$\mathrm{p}$ value ${ }^{2}$} \\
\hline & Control & $\mathrm{T} 1$ & $\mathrm{~T} 2$ & $\mathrm{~T} 3$ & & All & $\mathrm{C}$ vs T \\
\hline General bacteria & $7.05 \mathrm{E}+08$ & $5.40 \mathrm{E}+08$ & $4.55 \mathrm{E}+08$ & $6.07 \mathrm{E}+08$ & $3.23 \mathrm{E}+08$ & 0.965 & 0.704 \\
\hline Methanogens & $4.23 \mathrm{E}+05$ & $6.70 \mathrm{E}+05$ & $2.84 \mathrm{E}+05$ & $3.75 \mathrm{E}+05$ & $9.76 \mathrm{E}+04$ & 0.265 & 0.886 \\
\hline Protozoa & $5.53 \mathrm{E}+04$ & $3.58 \mathrm{E}+05$ & $3.59 \mathrm{E}+05$ & $2.59 \mathrm{E}+05$ & $4.66 \mathrm{E}+04$ & 0.181 & 0.055 \\
\hline
\end{tabular}

SEM, standard error of the mean.

${ }^{1}$ Control: without lysozyme, T1: 2,000 unit lysozyme, T2: 4,000 unit lysozyme, T3: 8,000 unit lysozyme.

${ }^{2} \mathrm{C}$ vs $\mathrm{T}$ is the comparison between control and treatment. 
irrespective of incubation period is consistent with the findings of Quinn et al. (2009) and Zinn et al. (1997) where they observed no difference of DM and OM disappearance with the ionophores, antibiotics and sulphur supplementation in their in vitro digestion trial. This non-significant different $\mathrm{DM}$ and $\mathrm{OM}$ disappearance results are also consistent with the results observed by Soriano et al. (2014), where they elicited in vitro DM and OM disappearance with Lactobacillus mucosae on dried brewers grain. The results observed in our experiment tended towards higher DM and OM disappearance, whose ultimate effect on higher in vitro total VFA production supported by Van Dung et al. (2014), where they reported higher DM and OM disappearance with concentrate:roughage (8:2) substrate along with higher in vitro total VFA production. We found a significant decrease in $\mathrm{CH}_{4}$ concentration after 12 and $24 \mathrm{~h}$ of incubation which is in concordance with the result of Mamuad et al. (2014), where significantly lower in vitro $\mathrm{CH}_{4}$ concentration was revealed. Current experimental decreasing $\mathrm{CH}_{4}$ concentration was found with increasing lysozyme inclusion, suggesting a negative correlation between lysozyme amount and $\mathrm{CH}_{4}$ concentration. Present experimental lower $\mathrm{CH}_{4}$ concentration is also negatively correlated with the higher total VFA. Nyachoti et al. (2012) reported a tendency to increase propionate in piglets, when $0.1 \%$ and $0.2 \%$ of lysozyme were added to the basal diet. Current experimental lysozyme with high concentrate based substrate can produce higher propionate by the utilization of hydrogen $\left(\mathrm{H}_{2}\right)$ through the fumarate to succinate production pathway. On the other hand, methanogen generate $\mathrm{CH}_{4}$ from $\mathrm{CO}_{2}$ and $\mathrm{H}_{2}$ (Miller et al., 1986). So, lysozyme which facilitate $\mathrm{H}_{2}$ utilization can be the methanogen competitors. Ultimately, lysozyme inhibit $\mathrm{CH}_{4}$ production, presumably which reflected as lower $\mathrm{CH}_{4}$ concentration in this experiment. However, further in vivo study should be conducted to draw rigid conclusion.

We observed no differences in the general bacterial DNA copy number. The same non-significant results were found by Zhou et al. (2011) in an in vitro experiment using 2nitroethanol, sodium nitrate, and ethyl 2 butynote with the result of lower $\mathrm{CH}_{4}$ concentration. Thus, the lack of difference in general bacterial DNA copy number observed in the present study may be linked to the non-significant difference in DM and OM disappearance and TG production after 12 and $24 \mathrm{~h}$ of incubation period. However, we did see a tendency towards a lower general bacterial DNA copy number in the treatment groups compared to the control group. This result is supported by Salton (1957), in which the lysozyme digested bacterial cell wall as well as inducing microbial autolysis (Ibrahim et al., 2001) resulting in DNA autolysis, ultimately decreasing the DNA copy number. We found no differences in methanogen DNA copy number. Likewise, Zhou et al. (2011) found no difference in methanogen DNA copies log number among control and treatment groups, although compared to the control groups, a lower $\mathrm{CH}_{4}$ concentration was found in groups treated with a methanogen inhibitor (propynoic acid). In this connection, Ungerfeld et al. (2004) explained that different types of methanogens differ in their $\mathrm{CH}_{4}$ production potential and display different sensitivities to methanogen inhibitors. The amount of methanogen DNA copies log number found in our experiment is supported by the findings of Stiverson et al. (2011) who used samples from the adhering portion of sheep rumen and observed similar methanogen DNA log copy number as current experiment. We did not find any significant differences in protozoan DNA copy number with lower $\mathrm{CH}_{4}$ concentration in treatments group is in concordance with the result of Karnati et al. (2009), where they revealed a tendency to be lower $\mathrm{CH}_{4}$ concentration with non-significant different of protozoal $\mathrm{N}$ flow, using a continuous in vitro culture treatment with monensin. As seen in Table 5, however, protozoan DNA copy number is nearly $1 \log$ difference but result is statistically non-significant, this type of result also elicited by Zhou et al. (2011) where 1 log difference DNA copy showed non-significant difference. The protozoan DNA copies log number observed in the current study is supported by those found by Anantasook et al. (2013) who used urea treated rice straw and concentrate mixture with and without rain tree pod meal in an in vivo experiment using dairy steers.

\section{CONCLUSION}

Addition of 8,000 U lysozyme per g of DM feed substrate increased total VFA and decreased $\mathrm{CH}_{4}$ concentration which indicates that it is capable to improving in vitro rumen fermentation and reducing $\mathrm{CH}_{4}$ emission. Further in vitro studies should be conducted using higher doses of lysozyme, and in vivo trials are needed to draw rigid conclusions.

\section{CONFLICT OF INTEREST}

We certify that there is no conflict of interest with any financial organization regarding the material discussed in the manuscript.

\section{ACKNOWLEDGMENTS}

This research was supported by the Korea Institute of Planning and Evaluation for Technology in Food, Agriculture, Forestry and Fisheries (Project number 3140753). Authors also thankful to Dr. Byung-Hern Moon. Managing Director, CellTech for their technical support to this experiment. 


\section{REFERENCES}

Anantasook, N., M. Wanapat, A. Cherdthong, and P. Gunun. 2013. Changes of microbial population in the rumen of dairy steers as influenced by plant containing tannins and saponins and roughage to concentrate ratio. Asian Australas. J. Anim. Sci. 26:1583-1591.

Asanuma, N., M. Iwamoto, and T. Hino. 1999. Effect of the addition of fumarate on methane production by ruminal microorganisms in vitro. J. Dairy Sci. 82:780-787.

Chaney, A. L. and E. P. Marbach. 1962. Modified reagents for determination of urea and ammonia. Clin. Chem. 8:130-132.

Denman, S. E. and C. S. McSweeney. 2006. Development of a realtime PCR assay for monitoring anaerobic fungal and cellulolytic bacterial populations within the rumen. FEMS Microbiol. Ecol. 58:572-582.

Ellison, R. T. 3rd and T. J. Giehl. 1991. Killing of gram-negative bacteria by lactoferrin and lysozyme. J. Clin. Invest. 88:10801091.

Giraldo, L. A., M. D. Carro, M. J. Ranilla, and M. L. Tejido. 2007. Influence of fibrolytic enzymes on in vitro methane production and rumen fermentation of a substrate containing $60 \%$ of grass hay. Livest. Res. Rural Dev. 19:257-261.

Goncu, S., M. Gorgulu, and G. Gokce. 2012. The effect of additional lyzozyme to milk on growth performances of Holstein calves. J. Anim. Vet. Adv. 11:3724-3727.

Han, S., S. Kim, and H. Shin. 2005. UASB treatment of wastewater with VFA and alcohol generated during hydrogen fermentation of food waste. Process Biochem. 40:2897-2905.

Hattori, K. and H. Matsui. 2008. Diversity of fumarate reducing bacteria in the bovine rumen revealed by culture dependent and independent approaches. Anaerobe 14:87-93.

Ibrahim, H. R., T. Matsuzaki, and T. Aoki. 2001. Genetic evidence that antibacterial activity of lysozyme is independent of its catalytic function. FEBS Lett. 506:27-32.

Karnati, S., J. Sylvester, C. Ribeiro, L. Gilligan, and J. Firkins. 2009. Investigating unsaturated fat, monensin, or bromoethanesulfonate in continuous cultures retaining ruminal protozoa. I. Fermentation, biohydrogenation, and microbial protein synthesis. J. Dairy Sci. 92:3849-3860.

Kim, S., L. L. Mamuad, C. Jeong, Y. Choi, S. S. Lee, J. Ko, and S. Lee. 2013. In vitro evaluation of different feeds for their potential to generate methane and change methanogen diversity. Asian Australas. J. Anim. Sci. 26:1698-1707.

Mamuad, L., S. H. Kim, C. D. Jeong, Y. J. Choi, C. O. Jeon, and S. Lee. 2014. Effect of fumarate reducing bacteria on in vitro rumen fermentation, methane mitigation and microbial diversity. J. Microbiol. 52:120-128.

May, K. D., J. E. Wells, C. V. Maxwell, and W. T. Oliver. 2012. Granulated lysozyme as an alternative to antibiotics improves growth performance and small intestinal morphology of 10-dayold pigs. J. Anim. Sci. 90:1118-1125.
Miller, T. L., M. J. Wolin, H. X. Zhao, and M. P. Bryant. 1986. Characteristics of methanogens isolated from bovine rumen. Appl. Environ. Microbiol. 51:201-202.

Nyachoti, C. M., E. Kiarie, S. K. Bhandari, G. Zhang, and D. O. Krause. 2012. Weaned pig responses to Escherichia coli K88 oral challenge when receiving a lysozyme supplement. J. Anim. Sci. 90:252-260.

Ownes, F. N., D. S. Secrist, W. J. Hill, and D. R. Gill. 1998. Acidosis in cattle: A review. J. Anim. Sci. 76:275-286.

Quinn, M. J., M. L. May, K. E. Hales, N. DiLorenzo, J. Leibovich, D. R. Smith, and M. L. Galyean. 2009. Effects of ionophores and antibiotics on in vitro hydrogen sulfide production, dry matter disappearance, and total gas production in cultures with a steam-flaked corn-based substrate with or without added sulfur. J. Anim. Sci. 87:1705-1713.

Sahoo, N. R., P. Kumar, B. Bhusan, T. K. Bhattacharya, S. Dayal, and M. Sahoo. 2012. Lysozyme in livestock: A guide to selection for disease resistance: A review. J. Anim. Sci. Adv. 2:347-360.

Salton, M. R. J. 1957. The properties of lysozyme and its action on microorganisms. Bacteriol. Rev. 21:82-100.

SAS (Statistical Analysis System) Institute Inc. 2004. SAS/STAT User's Guide. version 9.1. SAS Institute Inc. Cary, NC, USA.

Soriano, A. P., L. L. Mamuad, S. H. Kim, Y. J. Choi, C. D. Jeong, G. S. Bae, M. B. Chang, and S. S. Lee. 2014. Effect of Lactobacillus mucosae on in vitro rumen fermentation characteristics of dried brewers grain, methane production and bacterial diversity. Asian Australas. J. Anim. Sci. 27:1562-1570.

Stiverson, J., M. Morrison, and Z. Yu. 2011. Populations of select cultured and uncultured bacteria in the rumen of sheep and the effect of diets and ruminal fractions. Int. J. Microbiol. 2011:750613.

Tabaru, H., E. Kadota, H. Yamada, N. Sasaki, and A. Takeuchi. 1988. Determination of volatile fatty acids and lactic acid in bovine plasma and ruminal fluid by high performance liquid chromatography. Jpn. J. Vet. Sci. 50:1124-1126.

Ungerfeld, E. M., S. R. Rust, D. R. Boone, and Y. Liu. 2004. Effects of several inhibitors on pure cultures of ruminal methanogens. J. Appl. Microbiol. 97:520-526.

Van Dung, D., W. Shang, and W. Yao. 2014. Effect of crude protein levels in concentrate and concentrate levels in diet on in vitro fermentation. Asian Australas. J. Anim. Sci. 27:797-805.

Zhou, Z., Q. Meng, and Z. Yu. 2011. Effects of methanogenic inhibitors on methane production and abundances of methanogens and cellulolytic bacteria in in vitro ruminal cultures. Appl. Environ. Microbiol. 77:2634-2639.

Zinn, R. A., E. Alvarez, M. Mendez, M. Montano, E. Ramirez, and Y. Shen. 1997. Influence of dietary sulfur level on growth performance and digestive function in feedlot cattle. J. Anim. Sci. 75:1723-1728. 